\title{
ROLE OF SUSTAINABLE WHEAT PRODUCTION TO ENSURE FOOD SECURITY IN THE CWANA REGION
}

\author{
W. Tadesse*, H. Halila, M. Jamal, S. El-Hanafi, S. Assefa, T.Oweis, M. Baum \\ International Centre for Agricultural Research in Dry Areas (ICARDA), Rabat Morocco
}

Received - April 20, 2017; Revision - May 30, 2017; Accepted - June 01, 2017

Available Online - August 31, 2017

DOI: http://dx.doi.org/10.18006/2017.5(Spl-1-SAFSAW).S15.S32

KEYWORDS
Wheat
technologies
intensification
food security
CWANA

* Corresponding author

E-mail: w.tadesse@cgiar.org (W. Tadesse)

Peer review under responsibility of Journal of Experimental Biology and Agricultural Sciences.

Production and Hosting by Horizon Publisher India [HPI] (http://www.horizonpublisherindia.in/).

All rights reserved.

\begin{abstract}
Wheat is the world's most widely cultivated cereal. By 2050, global demand for wheat is projected to increase by $60 \%$. In the CWANA region which ICARDA is tasked to serve, wheat is the basic staple and food security crop, contributing over $60 \%$ of people's daily calorific and protein needs. Due to the large proportion of subsistence farmers, wheat production also has a major impact on household food security. Despite this, the productivity of wheat in the region is very low (less than $2.5 \mathrm{t} / \mathrm{ha}$ ) due largely to the major abiotic (drought, cold, heat, salinity) and biotic (stripe rust, leaf rust, stem rust and Hessian fly) stresses encountered. Most countries in the region are net importers of wheat for human consumption, with regional demand predicted to continue rising. Egypt alone currently imports 9 million tons annually. The situation is further complicated by food production shortfalls associated with climate change which can cause food crises, civil unrest and even migration. The wheat breeding program at ICARDA has developed high yielding and heat tolerant wheat genotypes which have been tested and released as cultivars by many countries in the CWANA region. Out-scaling and intensification of wheat cultivars combined with other improved crop management practices have been carried out by ICARDA in partnership with the national programs in Algeria, Egypt, Iraq, Jordan, Morocco, Sudan, Syria, Tunisia and Yemen resulting with an average increase of wheat production by $28 \%$. The result clearly indicates that development and utilization of climate smart wheat technologies including high yielding and stress tolerant cultivars; integrated crop management systems; establishment of conducive policies and infrastructures are crucial to increase productivity and ensure food and nutrition security.
\end{abstract}

All the article published by Journal of Experimental Biology and Agricultural Sciences is licensed under a Creative Commons Attribution-NonCommercial 4.0 International License Based on a work at www.jebas.org.

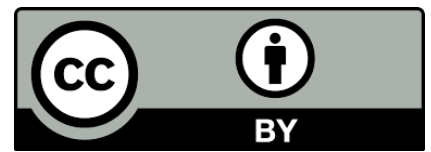




\section{Introduction}

Wheat is the principal staple food in most countries of the Central and West Asia and North Africa (CWANA) region, accounting for $45 \%$ of the region's per capita calorie intake with an average wheat consumption of about $200 \mathrm{~kg} /$ person/year, which is the highest in the world. The CWANA region is a vast geographic area extending west to east from the Atlas Mountains in Morocco to the fertile irrigated Indus valley in Pakistan, and from the highland, high-rainfall areas of Ethiopia in the south to the temperate and dry northern Kazakhstan. As expected, this vast geographic area is characterized by large variations in agroecology, farming systems, moisture, temperature, soil types and cultural practices. In addition, the region harbors all kinds of wild and cultivated wheat types of different growth habits. During the period 1961-2013, wheat production area has increased from 26.9 to 54 million ha, while total production and yield (t/ha) increased from 22 to 122 million tons and from 1.1 to 2.6 t/ha, respectively (Figure 1).

The increase in production is mainly due to the adoption of improved wheat cultivars originated from the International Maize and Wheat Improvement Center (CIMMYT) and the International Center for Agricultural Research in the Dry Areas (ICARDA), utilization of inputs, better agronomic practices, increased area of production, and favorable policies. The most important wheat growing countries in the region (Table 1) are in decreasing order viz. Kazakhstan (13.7 Mha), Pakistan (8.9 Mha), Turkey (7.9Mha), Iran (6.8Mha), Morocco (3.0 Mha),
Afghanistan (2.4 Mha), Algeria (1.8 Mha), Ethiopia (1.6 Mha), Syria (1.5 Mha), Uzbekistan (1.4 Mha) and Egypt (1.3 Mha).

As indicated in Figure 2, there is a huge difference between production and consumption in the CWANA region. There is not sufficient production at the regional level to cope with the increasing demand for wheat consumption.

Most of the countries in the CWANA region except Kazakhstan, Syria, Pakistan and Turkey are not self-sufficient in wheat production, and accordingly, wheat is their single most important imported commodity. Among North African countries, Egypt is the largest importer with 9 million tons of wheat imported every year. According to Shiferaw et al. (2013), demand for wheat is growing at $5.6 \%$ and $2.2 \%$ /year in Central Asia and North Africa, respectively. In the year 2050, the population in CWANA is expected to increase from the current 0.9 billion to 1.4 billion, and the demand for wheat will rise from the present 164 million tons to 268 million tons, calling for more research and development efforts to increase wheat productivity at the regional and global levels to meet the needs of the increasing population.

CWANA also hosts some of the most damaging and virulent races of diseases and pests. Farmers are typically required to apply fungicide and pesticides multiple times during their cropping season to avoid near complete losses. These chemical products are often at a premium in the small rural markets of CWANA and their availability far from certain. Furthermore, farmers are rarely trained in the deployment of integrated pest management (IPM) practices; the results of IPM malpractices can be the rapid

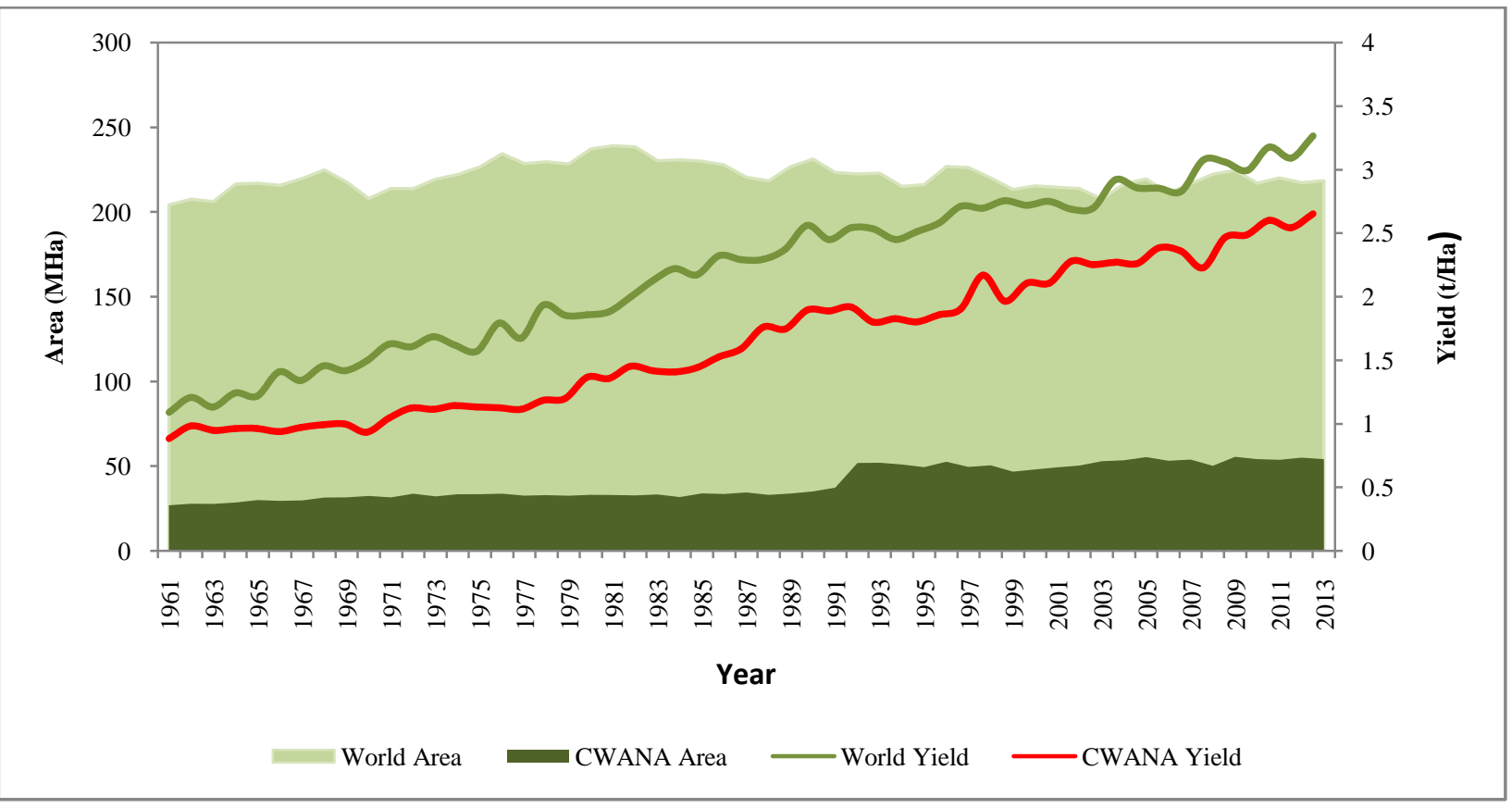

Figure 1Trends in wheat area, production and yield at Global and CWANA level1961-2013 (FAO, 2015) 
Table 1 Average area, production and yield of wheat from 2009-2013 in wheat growing countries of the CWANA region

\begin{tabular}{|c|c|c|c|c|}
\hline Country & Region & Area (Million ha) & Production (Million tons) & Yield $\left(\mathrm{t} \mathrm{ha}^{-1}\right)$ \\
\hline Afghanistan & Central Asia & 2.45 & 4.64 & 1.89 \\
\hline Algeria & North Africa & 1.79 & 2.97 & 1.66 \\
\hline Egypt & North Africa & 1.33 & 8.47 & 6.35 \\
\hline Ethiopia & North Africa/Sub Saharan Africa & 1.60 & 3.26 & 2.03 \\
\hline Iran (Islamic Republic) & West Asia & 6.82 & 13.42 & 1.97 \\
\hline Iraq & West Asia & 1.36 & 2.90 & 2.11 \\
\hline Jordan & West Asia & 0.02 & 0.02 & 1.16 \\
\hline Kazakhstan & Central Asia & 13.70 & 14.64 & 1.07 \\
\hline Kyrgyzstan & Central Asia & 0.36 & 0.81 & 2.20 \\
\hline Lebanon & West Asia & 0.04 & 0.12 & 3.38 \\
\hline Libya & North Africa & 0.15 & 0.16 & 1.03 \\
\hline Morocco & North Africa & 3.05 & 5.62 & 1.84 \\
\hline Pakistan & Central Asia & 8.88 & 24.05 & 2.71 \\
\hline Saudi Arabia & West Asia & 0.18 & 1.01 & 5.60 \\
\hline Sudan & North Africa/Sub Saharan Africa & 0.23 & 0.39 & 1.74 \\
\hline Syrian Arab Republic & West Asia & 1.51 & 3.49 & 2.32 \\
\hline Tajikistan & Central Asia & 0.33 & 0.89 & 2.70 \\
\hline Tunisia & North Africa & 0.65 & 1.32 & 2.00 \\
\hline Turkey & West Asia & 7.92 & 20.84 & 2.63 \\
\hline Turkmenistan & Central Asia & 0.72 & 1.59 & 2.20 \\
\hline Uzbekistan & Central Asia & 1.42 & 6.67 & 4.70 \\
\hline \multirow[t]{6}{*}{ Yemen } & West Asia & 0.13 & 0.24 & 1.81 \\
\hline & North Africa & 1.40 & 3.71 & 2.57 \\
\hline & West Asia & 2.25 & 5.26 & 2.62 \\
\hline & Central Asia & 3.98 & 7.61 & 2.50 \\
\hline & CWANA & 54.52 & 117.20 & 2.55 \\
\hline & World & 219.52 & 684.02 & 3.12 \\
\hline
\end{tabular}




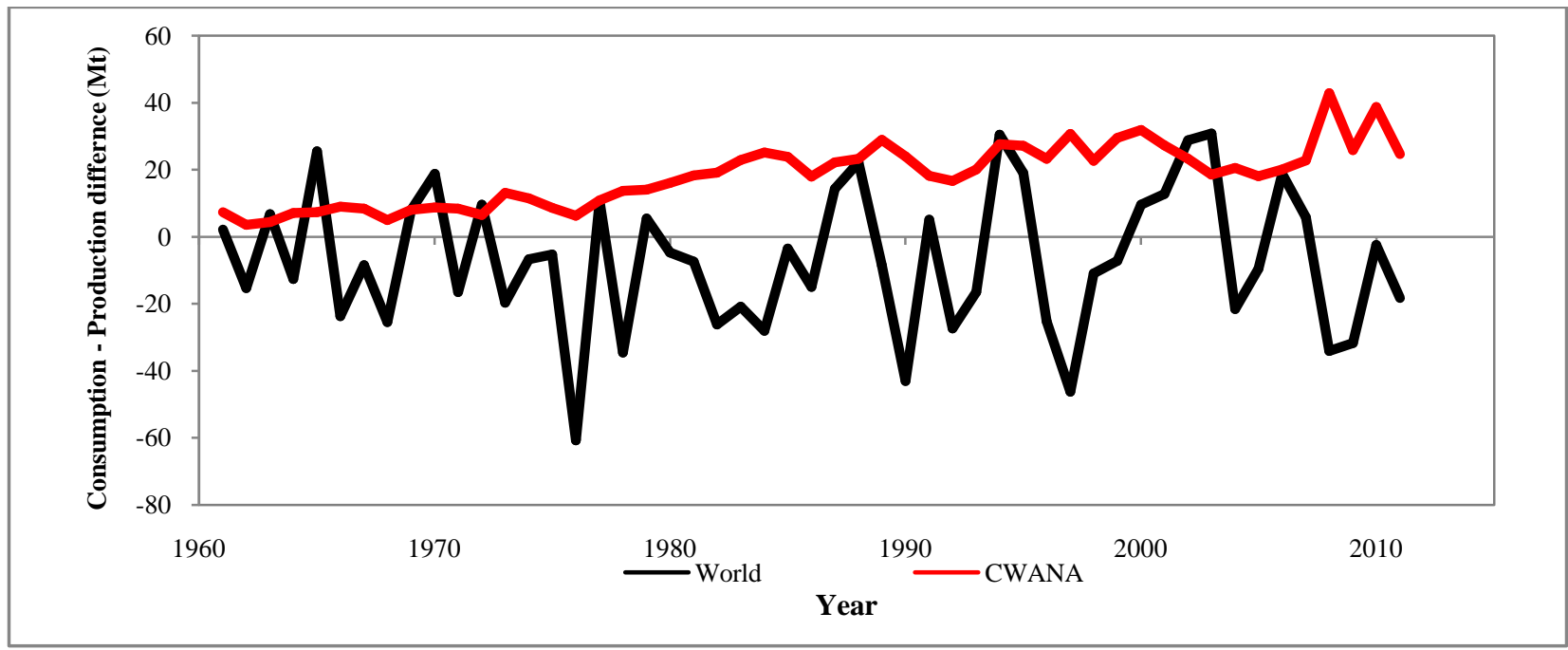

Figure 2 Wheat consumption and production difference at global and CWANA levels, 1961-2011 (FAO, 2017)

development of novel races with acquired resistance to the pesticides.

\section{Major wheat production environments}

According to Rajaram et al. (1995), a mega-environment (ME) is a region with similar climate, moisture regimes, soil types, growth habit, plant performance, prevalent diseases and insect pests. Thus, based on moisture availability, cropping systems and temperature regimes, the wheat production area in the CWANA region can be classified under five distinct large megaenvironments (E) namely: (E1) Favorable Irrigated and High Rainfall Spring Wheat Environment of CWANA that covers over 13.0 million hectares; (E2) Semi-arid (Mediterranean Rain-fed) Spring Wheat Environment with about 11.0 million hectares; (E3) Favorable Irrigated Winter/Facultative Wheat Environment covers an area of 5.4 million hectares.; (E4) Semi-arid Rainfed Winter/Facultative Wheat Environment has an area of Approximately 12.7 million hectares; and (E5) the High Latitude (Spring Planted) Spring Wheat Environment with approximately 8.0 million hectares, all in Northern Kazakhstan. The area under wheat cultivation in North Africa, West Asia, Central Asia and the Caucasus, and the Nile Valley sub-regions is characterized by large variation in agro-ecology, farming systems, moisture, temperature, soil types, races of pests, and cultural practices. In these sub-regions most of rainfed wheat farmers, whose livelihoods solely depend on income from wheat grain, fodder and straw production, live in areas with less than $350 \mathrm{~mm}$ of rainfall per annum. Hence, the adverse effects of the harsh climate, poor soil conditions, crop diseases and insects resulted generally in low and highly variable wheat production. Because of these complexities, it is prudent that international breeding programs take the mega-environment approach and use the shuttle breeding and multi-location yield trial strategy to develop high-yielding genotypes with wide or known specific adaptation.

\section{Challenges to wheat production}

\subsection{Abiotic and biotic stresses}

Significant proportion of the wheat production in the CWANA region is predominantly grown in rain-fed conditions, where the distribution of rainfall is erratic and sometimes causes problems with germination and often causes terminal moisture stress. Water is becoming scarce even in areas where wheat production depends on the use of supplementary irrigation. This is further accentuated by the increasing incidence of climate change, characterized by rising temperature (heat), less and erratic rainfall (drought) or sometimes excessive rainfall (flooding), and when combined with virulent pests and diseases, it makes agricultural productivity less predictable. Wheat is affected by many diseases such as rusts (Puccinia spp.), septoria (Septoria tritici), tan spot (Pyrenophora triticirepentis), fusarium (Fusarium spp.), powdery mildew (Blumeria graminis f. sp. Tritici), the bunts and smuts (Tilletia tritici), take-all (Gaeumannomyces graminis), and root rots (Cochliobolus sativus). Yield loss estimates for each disease vary from country to country and season to season. Of all the insects attacking wheat crop, Hessian fly (Mayetiola destructor), Sunn pest, wheat stem sawfly and Russian wheat aphids cause significant economic losses. Hessian fly damage can result in total loss of the crop if high infestations occur in the early stages of crop development. In Morocco, bread wheat and durum wheat 
yield losses due to Hessian fly have been estimated annually at $36 \%$ and $32 \%$, respectively, amounting to about US\$200 million/annum (Lhaloui et al., 1992). Sunn pest (Eurygaster integriceps Puton) affects some 15 million ha of wheat in West and Central Asia. With the current climate change effects, it is anticipated that new pests and diseases will emerge as already exemplified in the recent epidemics of stripe/yellow rust across the Central \& West Asia and North Africa (CWANA) region and the Ug99 stem rust epidemic in East African countries (Solh et al., 2012). The effect of climate change is also affecting the quality of wheat as increasing $\mathrm{CO}_{2}$ may negatively affect $\mathrm{N}$ content and protein quality and content and increasing temperatures can negatively affect grain size and protein quality. Modeling results indicate that wheat production will be more affected by climate change in the developing countries than the developed countries (Braun et al., 2010).

\subsection{Limited availability and high price of inputs}

As has been clearly witnessed as a result of the Green Revolution, increasing yield per unit area has been achieved mainly through the application and utilization of inputs such as improved cultivars, irrigation, fertilizers and pesticides. However, the costs of these inputs are also rising and are sometimes unaffordable to poor farmers in developing countries. Rising energy costs for example have contributed to higher fertilizer prices, because the costs of natural gas used to produce ammonia is increasing, and indirectly through higher transportation costs. Such rapid increases in input costs offset wheat production and pose a disincentive to wheat producers.

\subsection{Yield gap, Stagnating yield and increasing population}

In the year 2050, the world population is estimated to be 9 billion, while the demand for wheat is estimated to reach more than 900 million tons (Dixon et al., 2009). The current annual production level of about 126 million tons of wheat on a total area of 54 million hectares in the CWANA region is far below the regional demand of about 164 million tons. Such imbalance between demand and production has led to the importation of 44 million tons of wheat at a cost of 15 billion dollars during 2011 alone. Occasionally, a price hike in wheat can also cause political instability as has been seen with the price hikes in 2008. In the year 2050, the CWANA population is expected to increase from the current 0.9 billion to 1.4 billion, and the demand for wheat will reach 268 million tons.

Fulfilling this demand is challenging amid reports of yield stagnation in major wheat growing regions of the world and in the face of the expected adverse effects of climate change. Yield stagnation is a complex issue, which might be the result of a combination of factors, such as approaching a genetic ceiling in wheat improvement, declining soil fertility, unfavorable policies and marketing, biotic and abiotic stresses associated with climate change and other factors. Some authors have attributed yield stagnation to the genetic ceiling in India and Europe (Nagarajan, 2005) while others have reported the presence of genetic gain in both spring wheat (Manes et al., 2012; Sharma et al., 2012) and facultative winter wheat (Tadesse et al., 2013). However, it is evident that the potential of new cultivars have not been fully utilized in most of the developing countries due to poor agronomic management, application of incomplete packages of inputs, reduced incentives and unstable market prices. Recent yield gap analysis at global level in wheat indicated that the range in the difference between potential yield and farm yield in most countries although narrowing ranges between $26 \%$ to $69 \%$ with an average of $48 \%$ (Fischer et al., 2014). At regional level, especially in most developing countries of the CWANA region, there is still a huge yield gap. According to Pala et al. (2011), average yield gaps in Morocco ranged from 98-207\% in rainfed areas and from $51-89 \%$ in irrigated areas. Similarly yield gaps of $82-125 \%$ and $61-201 \%$ have been reported in Syria and Turkey, respectively.

\section{Improved technologies to enhance wheat production}

\subsection{Modern cultivars (MCs)}

The CGIAR centers (ICARDA \&CIMMYT) have been playing significant roles in germplasm development and distribution and capacity building (training) of the national programs. The wheat breeding program at ICARDA applies both conventional and molecular breeding approaches and techniques in order to develop high yielding and widely adapted germplasm with resistance/tolerance to the major biotic and abiotic constraints prevailing in the developing world (Tadesse et al., 2012a; Tadesse et al., 2012b; Tadesse et al., 2016). Some of these strategies and techniques include classification of Mega-Environments (ME) and assembling of targeted crossing blocks, shuttle breeding, utilization of doubled haploids (DH) and marker assisted selection (MAS), key location yield trials, distribution of germplasm to NARS through international nurseries, and partnership \& capacity building of NARS (Ferrara et al., 1987; Rajaram et al., 1995, vanGinkel et al., 2002; Tadesse et al., 2016).

The spring bread wheat breeding program at ICARDA undertakes more than 3000 crosses on annual basis. Germplasm generations are segregated and shuttled between Terbol station in Lebanon (F1), Sids station in Egypt (F2), Kulumsa station in Ethiopia (F3) and Merchouch station in Morocco (F4). This is followed by key location yield testing for preliminary and advanced yield trials at Terbol and Kheferdan (Lebanon), (MarchouchandJammatshaim (Morocco) Sids (Egypt), Wadmedani (Sudan) and Izmir (Turkey) 


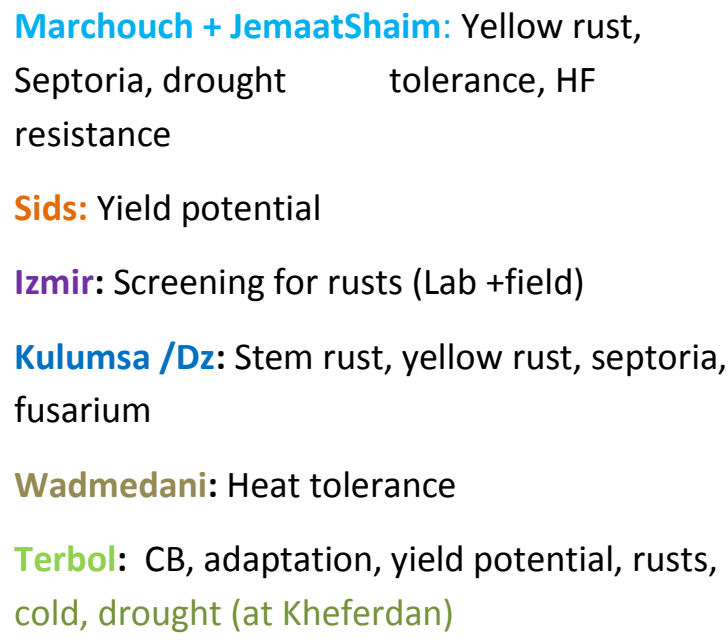

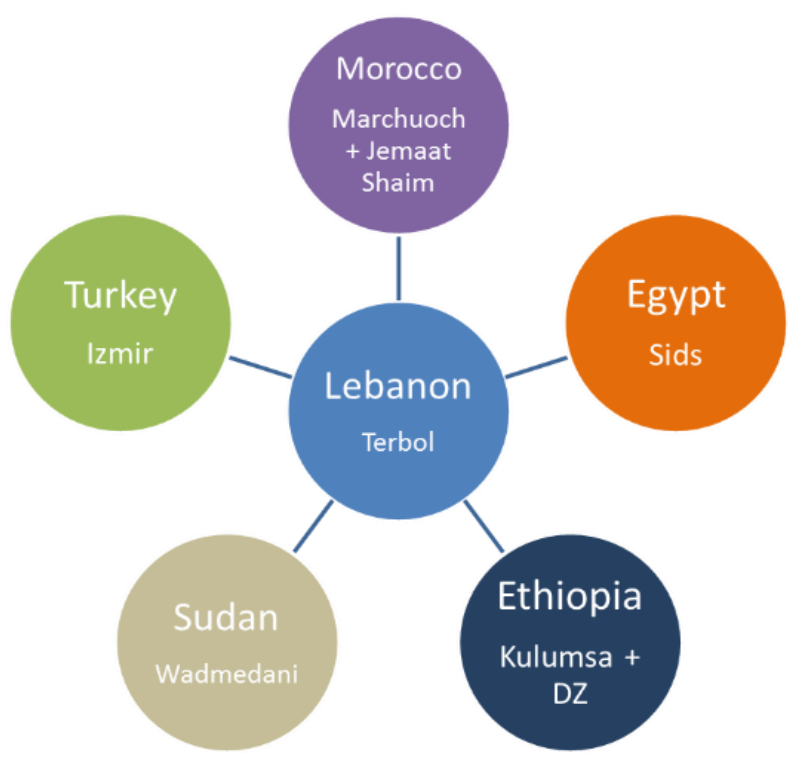

Fig.3: Key locations for ICARDA's wheat breeding tests

and Kulumsa (Ethiopia). This enables to combine yield potential and wide adaptation with resistance to biotic and abiotic stresses.

On annual basis, the spring bread wheat program composes and distributes more than 450 elite sets of genotypes through international nurseries and yield trials to countries in the CWANA and SSA regions and beyond upon request for potential direct release/or parentage purposes.

Wheat breeding in the CWANA region is predominantly carried out by Agricultural Research Institutes (ARIs) and Agricultural Universities of the respective countries. Some of the research institutes and universities have reasonable number of research centers, sub centers and testing sites addressing the major agro-

ecologies of each country. However, even in these institutes and centers, the internal research facilities and manpower are very limited both in quality and quantity which is a major problem across all countries. Withstanding these challenges and constraints, the national breeding programs have been operating to develop high yielding wheat cultivars with resistance/tolerance to the major biotic and abiotic constraints prevailing in the different agro-ecologies of each country.

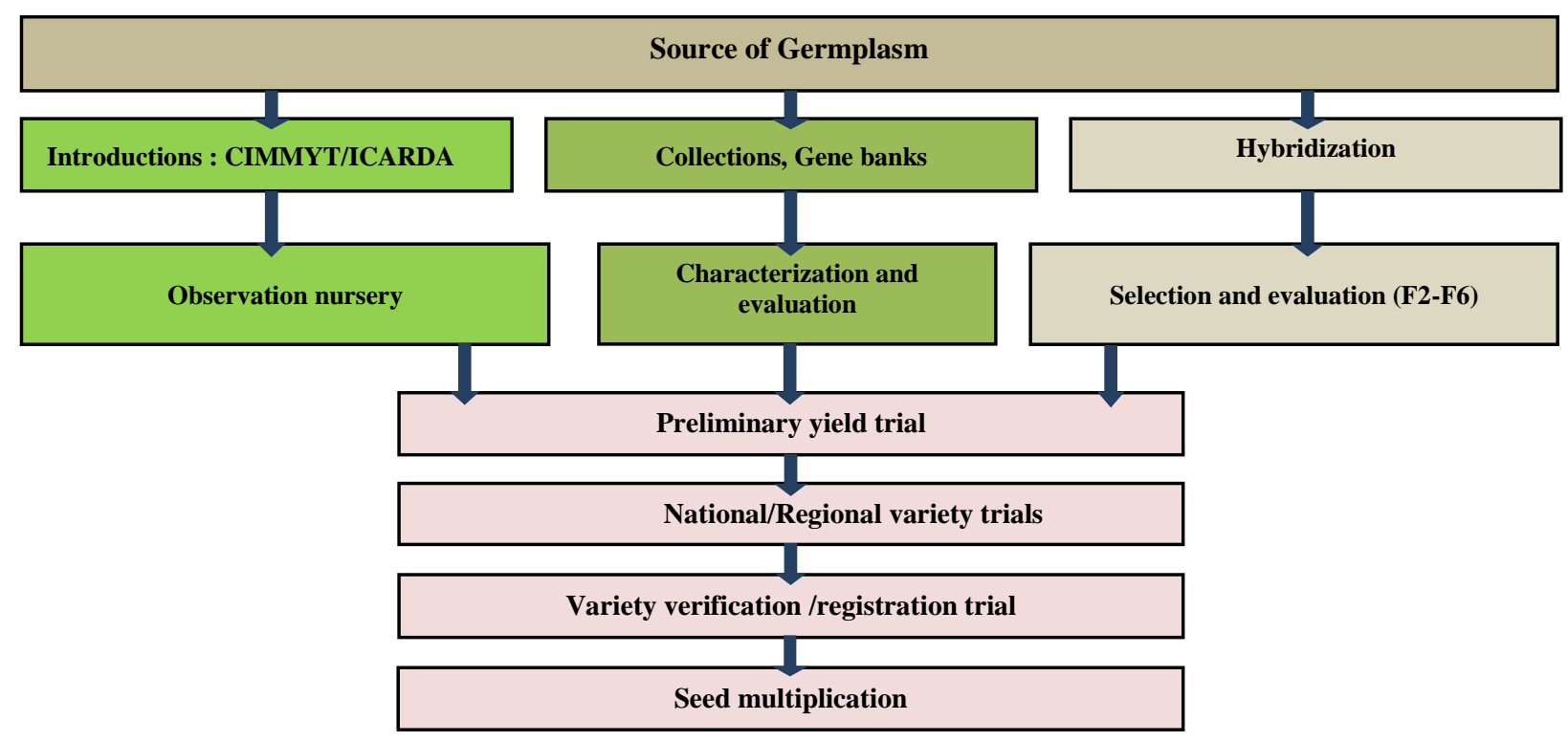

Figure 4 Germplasm acquisition and evaluation scheme in the national breeding programmes 
The germplasm acquisition, development, evaluation and release follows the general procedure outlined in Figure 4 with slight modification at country levels. The national wheat research coordinating center of each country requests international wheat nurseries from ICARDA and CIMMYT, and grows the nurseries for further evaluation and selection either for direct release or parental purposes. Fixed germplasm obtained from the international centers or from the national programs is evaluated across locations in preliminary yield trial (PYT) for 1 year followed by National/Regional variety trials (NVT/RVT) across locations for 2 years. Breeders need to apply for variety registration/release by submitting 2 years of the NVT/RVT data across locations along with the candidates and check cultivars performance. After submission confirmation, the best 2-3 candidate cultivars along with local and recent check cultivars will be promoted into variety verification/registration trial (VVT) in which each variety is planted on $10 \mathrm{~m} \times 10 \mathrm{~m}$ non replicated plots for 1 year both on station and on farm. Evaluation is made by the technical committee for variety release at grain filling stage and assessment will be carried out for resistance to diseases, maturity, yield potential and farmer's preference. The technical committee reports its assessment to the National variety release committee which makes decision to release, reject or repeat the variety verification trial. Upon acceptance/release, $50-100 \mathrm{~kg}$ of breeder seed should be submitted to the national/regional seed enterprises for multiplication of pre-basic, basic and certified seed. Following these procedures, many cultivars have been released by national programs. However, only few of the cultivars were widely grown and adopted by farmers in each country (Table 2).

Table 2 Pedigree of major wheat cultivars grown in selected countries of the WANA region

\begin{tabular}{|c|c|c|c|c|}
\hline Variety & Cross/pedigree & Selection history & Year of release & Country \\
\hline Pamir-94 & Ymh/Tob//Mcd/3/Lira & SWM12289-7M-0M-8M-1M-3WM-0WM & & Afghanistan \\
\hline Ghori 96 (= Prew) & Prl/Pew & CM59377-3AP-1AP-3AP-2AP-1AP-0AP & 1996 & Afghanistan \\
\hline Arz & Mayo54E/Lr//Tac/3/Lr64//Tzpp/Y54 & II21419-288-0LBY & 1973 & Algeria \\
\hline HD 1220 & $\mathrm{HD} 1220 / 3 * \mathrm{Kal} / \mathrm{Nal}$ & CM40454 & 1992 & Algeria \\
\hline Waha (Durum) & $\mathrm{Plc} / \mathrm{Ruff} / \mathrm{Gta} / \mathrm{Rtte}$ & CM17904 & 1986 & Algeria \\
\hline Giza-168 & Mil/Buc//Seri & CM93046-8M-0Y-0M-2Y-0B & 1999 & Egypt \\
\hline Sakha-93 & Sakha92/TR810328 & S8871-1S-2S-1S-0S & & Egypt \\
\hline Sohag3 (Durum) & Mexicali/Maghrebi72//51792/Durum\#6 & CD21831-2SH-1SH-0SH & 1991 & Egypt \\
\hline Kubsa & Attila & CM85836-50Y-0M-0Y-3M-0Y & 1996 & Ethiopia \\
\hline Digelu & Sha7/Kauz & CM95113-9Y-0M-0E-1Y-1Y-0M-0FC-FFUS & 2005 & Ethiopia \\
\hline Falat & Veery & CM33027-F-15M-500Y-0M-87B-0Y & 1990 & Iran \\
\hline Shroudy & Attila & CM85836-4Y-0M-0Y-8M-0Y-0PZ & 1997 & Iran \\
\hline $\begin{array}{l}\text { Yavaros C } 79 \\
\text { (Durum) }\end{array}$ & Jori/Anhinga//Flamingo & CM9799-126M-1M-5Y-0M & 1996 & Iran \\
\hline Achtar & Hork/Ymh//Kal/Bb & - & 1988 & Morocco \\
\hline Aguilal & Sais*2/KS85241-14 & - & 1997 & Morocco \\
\hline Arrehane & L222 (KLDN) & - & 1997 & Morocco \\
\hline Karim (Durum) & $\mathrm{Jo} / \mathrm{Aa} / / \mathrm{Fg}$ & CM9799 & 1985 & Morocco \\
\hline Seher 2006 & Chil/2*Star/4/Bow $/ /$ Buc/Pvn/3/2*Vee\#10 & CMSS95Y00645-100Y-200M-17Y-10M-0Y-0PAK & 2006 & Pakistan \\
\hline Pirsabak 08 & Kauz/Pastor & CMSS93B00025S-48Y-010M-010Y-4Y-0M & 2008 & Pakistan \\
\hline Imam & Attila & CM85836-50Y-0M-0Y-3M-0Y & 1996 & Sudan \\
\hline Cham-3 (Durum) & Durum-dwarf-S15/Crane//Geier-DW & CD523-3Y-1Y-2M-OY-OAP & 1987 & Syria \\
\hline Cham-5 (Durum) & Jori69/Hourani & LO589-4L-2AP-3AP-0AP & 1994 & Syria \\
\hline Cham-6 & W3918A/Jup & CM39992-8M-7Y-0M-0AP & 1991 & Syria \\
\hline Cham-8 & Kauz & CM67458 & 1998 & Syria \\
\hline Karim (Durum) & $\mathrm{Jo} / \mathrm{Aa} / / \mathrm{Fg}$ & CM9799 & 1980 & Tunisia \\
\hline Utique 96 & Attila & CM85836-50Y-0M-0Y-3M-0Y & 1996 & Tunisia \\
\hline Bezostaya 1 & Lutescens17/Skorospelka2 & - & 1970 & Turkey \\
\hline Firat 93 (Durum) & $\mathrm{Aa} / \mathrm{Vol} / / \mathrm{Fg} / 3 / \mathrm{Shaw}$ & CM27807-G-1M-2Y-1Y-0M or CM2798-6-1M-2Y-1Y-OM & 2002 & Turkey \\
\hline Gerek 79 & Men//My48/4-11/3/YY305 & & 1979 & Turkey \\
\hline
\end{tabular}


Among the many released wheat cultivars to-date, the most important cultivars currently grown in the CWANA region are indicated in Table 2 . The Veery cross $(=\mathrm{Kvz} / \mathrm{Buho} / / \mathrm{Kal} / \mathrm{Bb})$ and its derivatives have been by far the most successful cross as proven by its release as at least 65 cultivars in more than 30 countries. Among the Veery's, Veery 5 (CM33027-F-15M-500Y$0 \mathrm{M})$, was the most popular and was released in many countries with different local names such as Aziz in Yemen, Dashen in Ethiopia, GIZA 164 in Egypt, Loerie in Zambia, MACS2496 in India, Pirsabak 85 in Pakistan, Rassol in Iran, Sasaraib in Sudan, SCW101 in Zimbabwe, Seri 82 in Lebanon, Mexico, and Turkey, Tausi in Tanzania, andTilila in Morocco. After the Veery's, Nesser (= W3918A/Jup) was released and grown in Algeria, Iraq, Jordan, Lebanon and Syria. Similarly, Kauz (= Jup/Bjy//Ures) was released in many countries with such different local names as Atrak in Iran, Bacanora in Mexico, Cham-8 in Syria, Mehdia in Morocco, Tanur in Lebanon, WH542 in India, and under other local names in many more countries. After Kauz, many successful cultivars originated from the Attila cross (= $\mathrm{ND} / \mathrm{VG} 9144 / / \mathrm{Kal} / \mathrm{Bb} / 3 / \mathrm{Yaco} / 4 / \mathrm{Vee}$ 5) and grown in many countries as mega-cultivars such as Chamran, Gaher and Shroudy in Iran, Imam in Sudan, Kubsa in Ethiopia, MH-97 in Pakistan, PBW343 in India, Utique 96 in Tunisia, Ziyabey 98 in Jordan, and under different local names in many other countries (Tadesse et al., 2010).

The continuous supply of improved germplasm from the International Wheat Improvement Network (IWIN), an alliance of NARS, CIMMYT, ICARDA, and advanced research institutes (ARIs) for nearly half a century has made major contributions leading to major gains during and after the Green Revolution, and also enabled developing countries to have a sustained increase of wheat production and productivity, and thereby improved food security and farmers' livelihoods (Payne, 2004; Reynolds \& Borlaug, 2006, Trethowan et al., 2007). The success of wheat improvement within the CGIAR has been remarkable. More than $50 \%$ of the wheat cultivars grown in the CWANA region originated from CIMMYT/ICARDA programs (Figure 5).

The impact of wheat research has been witnessed not only by farmers, governments, policy makers and professionals but also by donors. According to World Bank (2008), wheat is the major crop with the highest percentage of farmers in the developing world that cultivate modern and improved cultivars.

\subsubsection{Breeding for drought tolerance}

Identification and development of wheat cultivars combining high-yield potential with water use efficiency can help stabilize yield gains in the face of drought and climate change. The development of wheat cultivars with early vigor and cold tolerance has been a major target of wheat breeders in dry land areas, as early and complete canopy establishment shades the soil and reduces evaporative loss from the soil surface, thereby significantly improving water productivity of wheat. High yielding and drought tolerant spring wheat genotypes have been identified from ICARDA's breeding program at the Marchouch station in Moroccoas indicated in Table 3.

\subsubsection{Development and deployment of high yielding and disease resistant wheat cultivars}

Among the major diseases known in wheat, stem/black rust and stripe/yellow rust are the most damaging and can cause very significant wheat yield losses. Developing and deploying

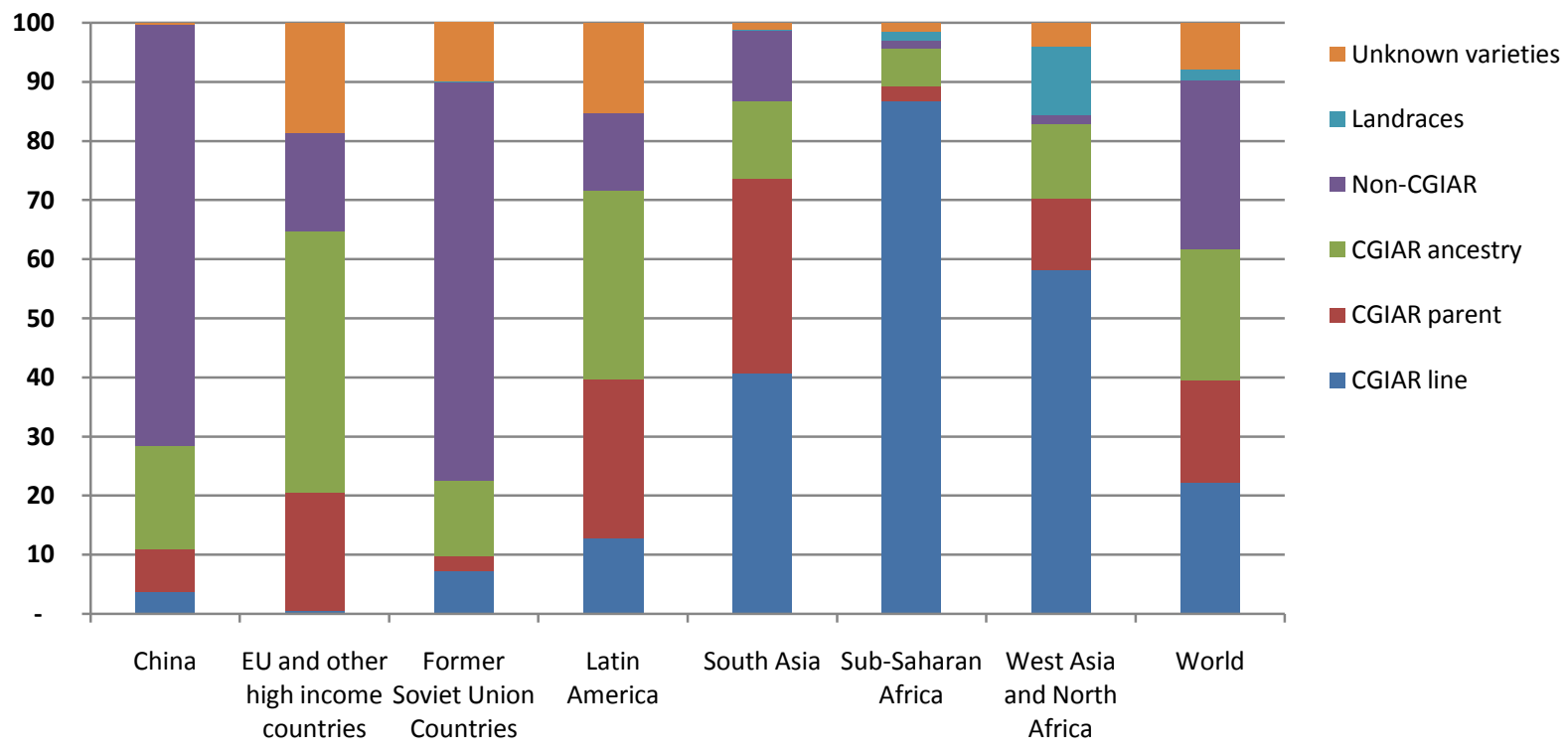

Figure 5 Percentage of wheat cultivars grown in the world by region and origin, 2014 (Lantican et al., 2015) 
Table 3 Performance of elite spring bread wheat genotypes at Merchouch, Morocco, 2014-2015

\begin{tabular}{|c|c|c|c|}
\hline Var No. & Pedigree & Yield (T/ha) & $\begin{array}{l}\text { Yield in \% of } \\
\text { Arrehane }\end{array}$ \\
\hline 1004 & KAUZ//MON/CROW'S'/3/SHUHA-4//NS732/HER/4/MILAN/PASTOR & 7.50 & 195.8 \\
\hline 1038 & JAWAHIR-1/GIRWILL-5 & 6.16 & 160.8 \\
\hline 1002 & SHUHA-4//NS732/HER/3/MILAN/DUCULA & 6.12 & 159.8 \\
\hline 1027 & SERI.1B*2/3/KAUZ*2/BOW//KAUZ/4/TRAP\#1/BOW//PFAU/3/MILAN & 5.71 & 149.0 \\
\hline 1013 & FLAG-3/ICARDA-SRRL-5 & 5.62 & 146.7 \\
\hline 1028 & KAUZ//ALTAR 84/AOS/3/MILAN/DUCULA & 5.58 & 145.6 \\
\hline 1014 & ATTILA 50Y//ATTILA/BCN/3/PFAU/MILAN & 5.56 & 145.2 \\
\hline 1015 & KAUZ//MON/CROW?S?/3/VEE/PJN//2*KAUZ & 5.52 & 144.1 \\
\hline 1037 & SERI.1B//KAUZ/HEVO/3/AMAD/4/FLAG-2 & 5.42 & 141.4 \\
\hline 1001 & SERI.1B//KAUZ/HEVO/3/AMAD/4/FLAG-2 & 5.16 & 134.6 \\
\hline 1016 & $\begin{array}{l}\text { SERI.1B//KAUZ/HEVO/3/AMAD/4/ATTILA//PSN/BOW/3/ATTILA/5/KAUZ' } \\
\text { S'/SHUHA-15 }\end{array}$ & 5.15 & 134.4 \\
\hline 1040 & Arrehane (national check) & 3.83 & 100.0 \\
\hline
\end{tabular}

genetically resistant cultivars adapted to target growing environments is the most economical and environmentally friendly strategy for controlling rust diseases of wheat, particularly for resource-poor farmers. However, because of the co-evolution of the host and pathogen, the deployment of individual resistance genes often leads to the selection and spread of new virulent pathogen mutants, and hence the 'boom and bust cycle' of cultivars performance continues. A new race of stem rust first identified in 1999 in Uganda (Ug99) became a global threat to the wheat industry as it overcame many of the known and most commonly used stem rust resistance genes, such as $\operatorname{Sr} 36, \operatorname{Sr} 31$, and $\mathrm{Sr} 24$. Similarly, the breakdown of stripe rust resistance gene $\operatorname{Yr} 9$ in cultivars derived from "Veery" lineage in the 1980's, and Yr27 in 2000's in major mega-cultivars derived from the "Attila" cross, such as MH97 (Pakistan), Kubsa (Ethiopia), PBW343 (India), and others such as Achtar in Morocco, Hidab in Algeria and many other cultivars in the CWANA region has caused significant wheat production losses of up to $70 \%$ (Solh et al., 2012).

The CGIAR centres (CIMMYT \& ICARDA) have carried out intensive screening and germplasm evaluation activities against the Ug99 race of stem rust at Njoro, Kenya and at DebreZeit, Ethiopia through the Borlaug Global Rust Initiative (BGRI) program. High yielding cultivars of CGIAR origin with resistance to Ug99 and other diseases such as stripe rust and septoria have been released recently and deployed in many countries (Table 4).

\subsubsection{Breeding for quality}

In most developing countries, apart from grain yield, disease resistance and drought/heat tolerance, grain quality has not been a strong criterion in variety selection. However, some NARS are beginning to critically look for high-quality cultivars suited for the preparation of a range of products. Cultivars such as Anza, Bezostaya, HD1220 and Pavon-76 are known for their excellent bread-making quality. These cultivars are still predominant in some countries not only because of their wide adaptation, high yield potential and stability, but also because of their high protein content and bread-making quality. With this understanding, the wheat breeding programs at ICARDA and CIMMYT routinely undertake evaluation of germplasm for quality traits following international standard grain quality procedures. Most of the currently available elite genotypes for both irrigated and rain-fed environments are acceptable to excellent in quality, with protein levels of 12 to $16 \%$. Most of these genotypes have the $5+10$ (GluD1), 7+8 (Glu-B1) and 2* (Glu-A1) glutenin subunit alleles, which are known to be highly correlated with superior protein quality. Recently through the Harvest Plus $(\mathrm{H}+)$ Challenge program, progress has been made in the development of biofortified wheat with improved zinc ( $\mathrm{Zn})$ and iron $(\mathrm{Fe})$ content in wheat grains in addition to protein content and quality. However, because of the negative correlation of yield and these quality traits, it may be difficult or require larger programs to combine high yield potential with high micronutrient grain content. 
Table 4 Recently released Ug99 stem rust resistant wheat cultivars of CGIAR-origin

\begin{tabular}{|c|c|c|c|c|c|}
\hline Variety Name & Type & Cross/Pedigree & Selection History & Year of Release & Country \\
\hline KINGBIRD & SBW & $\begin{array}{l}\text { TAM-200/TUI/6/PAVON-76//CAR-422/ANAHUAC- } \\
\text { 75/5/BOBWHITE/CROW//BUCKBUCK/PAVON-76/3/YECORA- } \\
\text { 70/4/TRAP-1 }\end{array}$ & CMSS99M00216-S-040M-030Y-0030M-16Y-2M-0Y & 2007 & Kenya \\
\hline DANPHE & SBW & KIRITATI//2*PBW-65/2*SERI.1-B & CGSS02B00119T-099B-099Y-099M-099Y-099M-24WGY-0B & 2008 & Ethiopia \\
\hline HOGGANA & SBW & PYN/BAU//MILAN (= ETBW 5780) & $\begin{array}{l}\text { CMSW94WM00188S-0300M-0100Y-0100M-15Y-8M-0Y-0IAP- } \\
\text { 0QTAP-0YT }\end{array}$ & 2011 & Ethiopia \\
\hline SHORIMA & SBW & UTQE96/3/PYN/BAU//MILAN & $\begin{array}{l}\text { ICW02-00330-4AP/0TS-0AP-030AP-10KUL-030KUL- } \\
\text { 0AP/0KUL-0DZ/0AP }\end{array}$ & 2011 & Ethiopia \\
\hline KARIM & SBW & T.AEST/SPRW//CA8055/3/BACANORA86 & ICW92-0477-1AP-1AP-4AP-1 AP-0AP & 2011 & Iran \\
\hline GOUMRIA-3 & SBW & VEE\#7/KAUZ & ICW94-0029-0L-1 AP-1 AP-7AP-0APS-0AP-0SD & 2013 & Sudan \\
\hline NORMAN & FWW & OR F1.158/FDL//BLO/3/SHI4414/CROW & ICWH860291-3AP-1AP-0AP-1AP-0AP & 2007 & Tajikistan \\
\hline $\begin{array}{l}\text { GIZIL } \\
\text { BUGDA }\end{array}$ & FWW & SAULESKU41/SADOVO1 & TCI950295-3AP-0AP-0E-1YE-0YE-1YM-0YM & 2009 & Azerbaijan \\
\hline NARC-2011 & SBW & OASIS/SKAUZ//4*BACANORA-88/3/2*PASTOR[3811]; & CMSS00Y01881T-050M-030Y-030M-030WGY-33M-0Y-0S & 2011 & Pakistan \\
\hline $\begin{array}{l}\text { MUQAWIM } \\
09\end{array}$ & SBW & OASIS/SUPER-KAUZ//4*BACANORA-88/3/2*PASTOR & CMSS00Y01881T-050M-030Y-030M-030WGY-33M-0Y-0S & 2009 & Afghanistan \\
\hline SUPER 152 & SBW & PFAU/SERI.1B//AMAD/3/WAXWING & CGSS02Y00153S-099M-099Y-099M-46Y-0B & 2011 & India \\
\hline MISR 1 & SBW & OASIS/SKAUZ//4*BCN/3/2*PASTOR & CMSS00Y01881T- 050M- 030Y-030M-030WGY-33M-0Y-0S & 2010 & Egypt \\
\hline
\end{tabular}




\subsubsection{Seed production and distribution}

Modern cultivars and seed technology play a significant role in increasing agricultural production and productivity, ensuring food and nutritional security and improving livelihoods of farming communities. A robust seed system provides farmers with sufficient quantity seed of appropriate quality at the right place and time, and at reasonable cost. There are relatively well functioning wheat seed sectors across most developing countries, dominated mainly by the public sector, both in terms of agricultural research (varietal releases) and seed delivery (quantity supplied). The diversification of the national seed sector led to the development of private sector wheat seed delivery in countries like Egypt, India, Morocco, Pakistan and Turkey (Bishaw, 2004). However, wheat being a self-pollinated crop, farm saved seed continues to dominate the landscape. As a result, the varietal replacement rate measured by the average age of cultivars in farmers' fields and average annual seed renewal rate measured by farmers regular purchase of certified seed remain low, with over 10 years and less than $20 \%$, respectively. These figures are worse in less favorable rain-fed areas and less accessible remote regions. In recent years, the emergence of rust threats and food prices spiking triggered renewed interest in food security in general and wheat seed supply in particular. For rapid deployment of stem rust resistant wheat cultivars in Egypt, Ethiopia and Pakistan, ICARDA, supported by a USAID project from 2009-2012, developed a strategy to fast-track testing and release of rust resistant wheat cultivars, massive extension and demonstration, accelerated seed multiplication of early generation seeds (breeder, pre-basic and basic seed), large-scale certified seed production by linking to existing public and/or private seed enterprises and onfarm seed production with farmer groups. In total, two cultivars in Egypt, eight cultivars in Ethiopia and five cultivars in Pakistan were released and substantial quantities of seed were produced and distributed under an accelerated scheme within the shortest possible period of time. In Egypt, 10,760 t certified seed were produced, which was sufficient to plant $7 \%$ of the total wheat area in Egypt; in Ethiopia, 27,000 t were produced sufficient to plant $10 \%$ of Ethiopia's total wheat area; and in Pakistan, 42,750 t certified seed were produced, sufficient to plant $5 \%$ of the total wheat area in Pakistan in 2011/13. Popularization and promotion of rust resistant cultivars has been reaching over 5,000 farmers every year in each of the three target countries.

\subsection{Sustainable Soil Nutrient Management}

Researchers and policy-makers must consider several soil and plant nutrient management options to sustain soil fertility, which includes Integrated Nutrient Management (INM) and involves the conjunctive use of fertilizers and organic sources. The Green Revolution, which was based on the intensive use of high-yielding cultivars of wheat coupled with other inputs like chemical fertilizers and irrigation water was successful in boosting food supply and reducing food prices. Critics of the Green Revolution, however, argue that the excessive application of chemical fertilizers has caused an imbalance in soil health by reducing soil fertility and increasing soil alkalinity. The challenge remains for scientists and farmers to work together to maintain soil health while increasing wheat production to meet growing demand. Organic manures are traditionally used to supply nutrients to plants. However, the volume of organic manure required to fertilize a unit area of land and other operational problems discourage their current use. Organic manure provides nutrients in an efficient way along with improving the soil conditions. Application of farmyard manure (FYM) helps to increase the yield and nutrient uptake by wheat. Incorporation of mustard/taramira + FYM and FYM at 10 t/ha has shown a significant increase in the grain yield wheat across years (Regar et al., 2005). Eight years of research on INM in a rice-wheat system at Jabalpur (India) revealed that conjunctive use of 5 t/ha FYM and $6 \mathrm{t} / \mathrm{ha}$ green manure with $90 \mathrm{~kg} \mathrm{~N} / \mathrm{ha}$ not only sustained the productivity of wheat, but also saved nearly 90-100 kg/ha fertilizer N (Singh et al., 2001).Blanket fertilizer nitrogen (N) recommendations for wheat production led to low $\mathrm{N}$-use efficiency due to field-to-field variability in soil $\mathrm{N}$ supply and seasonal variability in wheat yield. To achieve high $\mathrm{N}$-use efficiency, a site-specific $\mathrm{N}$ management strategy using GreenSeeker ${ }^{\mathrm{TM}}$ optical sensor is the best option. High N-use efficiency in irrigated wheat can be achieved by replacing blanket fertilizer recommendations by GreenSeek erorsiimiar optical sensor-based $\mathrm{N}$ management strategies consisting of applying moderate amounts of fertilizer $\mathrm{N}$ at planting and crown root initiation stages and GreenSeeker optical sensor-guided fertilizer $\mathrm{N}$ dosages at Feekes 5-6 or 7-8 stages of wheat. The utilization of information communication technologies (ICT), including computers, internet, geographical information systems, mobile phones, as well as traditional media such as radio or TV are playing important roles in large-scale deployment of site-specific recommendations to farmers and extension workers. Decision support systems (DSS) are now progressively used to facilitate application of improved nutrient management practices in farmers' fields. A recently developed DSS: "Nutrient Expert for Wheat" synthesized the wheat on-farm research data into a simple delivery system that enables wheat farmers to rapidly implement SSNM for their individual fields.

\subsection{Sustainable crop rotation systems}

In the irrigated part of the CWANA region such as Pakistan, Egypt, Turkey, Uzbekistan, rice-wheat or cotton-wheat rotation systems are commonly practiced. In such rotation system, wheat is planted during the cooler and drier winter season after rice or cotton, which is normally grown in the warm, sub-humid monsoon summer months. The late harvesting time of cotton pushes the wheat planting late into December, which in turn exposes wheat to heat stress during grain-filling in late April and 
May. The biggest challenge for this rotation comes from cotton residues, immobilizing key nutrients such as nitrogen, sulfur, phosphorus and potassium.

Legumes-wheat rotation system is the most common and sustainable rotation system in the rain-fed environments of the CWANA region. Legumes play an increasingly important role in rain-fed wheat production environments, especially in soils with low $\mathrm{N}$ content by enriching soil through biological $\mathrm{N}$ fixation, enhancing water use efficiency (WUE) and breaking the cycle of weeds, pests and diseases, which affect wheat production. Grain legume species and cultivars growing in the same location differ significantly in dry matter production, $\mathrm{N}$ accumulation, $\mathrm{N}_{2^{-}}$ fixation, N-balance and residue quality (Evans et al., 2001). These differences may be the main factors determining the residual $\mathrm{N}$ contribution to subsequent crops. Among the legumes, faba bean is the best nitrogen fixer with a mean of $100 \mathrm{~kg} \mathrm{~N} / \mathrm{ha}$, followed by groundnut and soybean (Smil, 1999). Many trial experiments have shown that the introduction of legumes, such as faba beans, chickpea, and field bean, in wheat-based cropping is a viable strategy for reducing the application of inorganic fertilizer and thus reducing the costs for resource poor small and medium scale farmers.

In the central plateau of Turkey, highlands of Eastern Algeria, and west Iran, the Wheat-Fallow (WF) system has been practiced for many years. The practice is a definite improvement over continuous cropping, as it stabilizes yields and provides farmers with a reliable income from year to year. However, the wheatfallow cropping system is an inefficient user of annual precipitation in regions where water is the major limiting factor. Production of wheat can be enhanced in this cropping system and more intensive rotations can be sustained by maximizing water storage and building soil residue to trap snow, absorb more rain, reduce runoff and minimize evaporation, as well as perform complete weed control at critical times in the production cycle.

\subsection{Conservation agriculture}

Conservation agriculture (CA), which has its roots in widespread principles of providing permanent soil cover, minimum soil disturbance and crop rotation, is now considered the principal road to sustainable agriculture, which enables increased farm productivity, while conserving the natural resource base. The decreased soil disturbance with ground cover keeps biological activity and organic matter decomposition near the surface and helps maintain a soil structure that allows greater infiltration of water associated with reduced soil water evaporation rates. Residue retention can also improve the water-holding capacity and long-term nutrient cycling. Moussadek (2012) found relatively lower hydraulic conductivity and absorptivity values under no-tillage compared to conventional tillage systems in the Zaers region of Morocco. CA practices enhance soil organic matter levels and nutrient availability by growing green manure/cover crops and returning their residues back to the soil. Thus, arable land under $\mathrm{CA}$ is more productive and for much longer periods of time. Increasing soil organic carbon (SOC) content showed positive impacts on soil physical properties, including increased stable aggregates (Mrabet et al., 2012). Moussadek et al. (2014) indicated that after five years of continuous no-tillage, the topsoil $(0-30 \mathrm{~cm}) \mathrm{SOC}$ values increased by $10 \%$ in the Vertisol, $8 \%$ in the Cambisol, and $2 \%$ in Luvisol, compared to conventional tillage.

CA improves soil structure and protects the soil against erosion and nutrient losses by maintaining a permanent soil cover and minimizing soil disturbance. In central Morocco, a reduction of $50 \%$ in soil losses was observed with no-till, having less than 2 $\mathrm{Mg} \mathrm{ha}{ }^{-1}$ of residue mulch compared to conventional till on a Vertisol (Moussadek et al., 2011). On a Mollisol, no-till reduced the runoff volume by $30-50 \%$ and sediment loss by $50-70 \%$ compared with disk ploughing. In comparison with chisel ploughing, no-till reduced runoff volume and sediment loss by respectively $24-53 \%$ and $43-65 \%$. This will increase water holding capacity and crop productivity particularly in drier seasons.

Farmers using CA technologies typically report higher wheat yields (up to $45-48 \%$ higher) with less water, fertilizer, pesticides, capital and labor inputs, thereby resulting in higher overall farm profits. Studies of no-tillage systems in Brazil and Paraguay indicated $10-70 \%$ saving of the conventional labor input depending on farming system and conventional tillage practice. Other benefits include a more even distribution of labor across the year, more timely operations, a reduction in drudgery, and opportunities for livelihoods diversification (Pieri et al., 2002). Reducing the time draft animals spend in one farmer's field means there is more time available for tilling additional land (if available) or hiring out their services to others. CA has proved particularly beneficial for many small holder farmers who do not have access to animal or mechanical tillage, since it enables them to carry out all their operations on time and precisely, increasing productivity and yield potential. On the other hand, the increasing demand of straw and crop residue for animal feed becomes a major challenge for proper expansion of conservation agriculture.

\subsection{Improved wheat water management}

Water is the most important input for crop production, and hence needs to be utilized efficiently and properly using better strategies and methods in both rain-fed and irrigated environments. The seasonal water requirement of wheat ranges from $450-650 \mathrm{~mm}$. Wheat can tolerate lower water supplies, but usually yields are lower when exposed to water stress. Generally, spring wheat is more sensitive to stress than winter wheat and flowering stage of growth for both types is the most sensitive to water shortage. The 
upper limit of wheat yields is 10-12 t/ha and wheat water productivity is about $2 \mathrm{~kg} / \mathrm{m}^{3}$ of net water use, which is only attainable under favorable conditions and good management (Passioura \& Angus, 2010). In rain-fed environments, the use of drought tolerant wheat cultivars with better agronomic managements such as dry planting, conservation agriculture, control of weeds and diseases will help to increase water use efficiency and productivity. Application of supplementary irrigation compensates for lower rainfall and less moisture storage, and it alleviates soil water stress during dry spells.

In northern Syria, applying supplementary irrigation (SI) one to three times $(100-300 \mathrm{~mm})$ in the spring increased wheat yields from 2 to $6 \mathrm{t} / \mathrm{ha}$ and water productivity from 0.5 to $2.0 \mathrm{~kg} / \mathrm{m}^{3}$ of water. Research in the central Anatolian highlands of Turkey and western Iran has shown that early wheat sowing by applying 50$70 \mathrm{~mm}$ of SI increased wheat yields by over $2 \mathrm{t} / \mathrm{ha}$. Finally, more inputs such as fertilizers can be applied and high yielding cultivars can be used, when favorable soil moisture is secured with SI (Ilbeyi et al., 2006).

In raised bed planting, wheat is grown in elevated strips of 1-1.25 $\mathrm{m}$ width between large furrows. In Egypt, since water is provided free of charge, ICARDA and the national research institutes failed to convince the farmers not to over-irrigate wheat. A program was initiated to adapt the raised bed practice within an integrated package at farmers' fields in the Nile Delta. The creation of the furrows at wide spaces encouraged the farmers to reduce water application as furrows cannot take more water, as is the case with close spacing in the traditional practice. The result of several years of research was that farmers automatically cut on water application by over $30 \%$ without any loss in yield. Additional improvement in the management practice included better fertility, weed control and landscape of the crop. The overall package increased yield by $25 \%$ and water use efficiency by over $50 \%$. Furthermore, a revolution in water saving and crop productivity was obtained with the adoption of a newly developed implements that simultaneously open the furrows and sows the seeds into the beds. The simplicity of the operation and reduced fuel cost was highly appreciated by the smallholder farmers in Egypt's Nile Delta. In just three years, 42,000 ha have shifted to the use of these new machines in combination with the developed management practice. This management practices now being outscaled to irrigated wheat areas in Eretria, Ethiopia, Iraq, Morocco Nigeria, and Sudan (ICARDA, 2013).

\subsection{Integrated pest management}

IPMuses a combination of cultural, physical, chemical and biological methods to control wheat pests by minimizing economic, health and environmental risks. The use of resistant cultivars, crop rotations and one time application of fungicides have been found to control most wheat diseases. Development and deployment of resistant cultivars against the Ug-99 race of stem rust and the Yr-27 virulent race of yellow rust have been carried out by many countries including Egypt, Iran, India, Pakistan, Nepal and Bangladesh. Through joint efforts between the National Institute of Agricultural Research (INRA) Morocco, ICARDA, and Kansas State University, ten resistance genes to Hessian fly have been identified in bread wheat. In addition, over a hundred other sources of resistance have been identified in wild relatives of wheat (El Bouhssini et al., 2012). Three bread wheat cultivars ('Massira' in 1996, 'Arrihane' and 'Aguilal' in 1998) have been released in Morocco. Despite similar efforts on durum wheat, only a single source of resistance has been identified to Hessian fly in Morocco. However, resistant lines were developed through the introgression of genes from bread wheat and wild relatives (T. araraticum) into durum wheat. Six resistant cultivars ('Irden', 'Chaoui', 'Marwane', 'Amria', 'Nassira' and 'Faraj') of durum wheat, with good grain quality and adaptation to Mediterranean dry lands were released in Morocco in 2003 and 2009.

IPM is also recommended to control the most important insect pests of wheat, such as Hessian fly, Sunn pest, Sawfly and Russian wheat aphid. Early planting and use of resistant wheat cultivars are effective in controlling Hessian fly. The IPM package for the control of Sunn pest has multiple components: changing spraying policy from indiscriminate aerial spraying to localized ground sprays based on economic insect population thresholds, devolution of control to farmers, enhancement/conservation of egg parasitoids through the use of flowering medicinal plants alongside wheat fields, and the use of entomopathogenic fungi in overwintering sites. Participatory approaches such as farmers' field schools have been used to disseminate IPM options for both Hessian fly and Sunn pest. Some elements of the Sunn pest package are being used by farmers on over 3 million hectares in several countries in West Asia. Use of insect resistant wheat cultivars (e.g. with solid-stem), swathing, tillage, delayed planting, crop rotation and the use of parasitoids have been recommended as effective IPM options in controlling wheat stem sawfly.

\section{Intensification of wheat technologies}

Agricultural extension (also known as agricultural advisory services), along with innovation, plays a crucial role in promoting agricultural productivity, increasing food security, improving rural livelihoods, and promoting agriculture as an engine of pro-poor economic growth. Many countries in the CWANA region such as Pakistan, Turkey, Iran, Syria, Egypt have launched credit systems market, information networks and extension services in order to demonstrate and diffuse wheat technology packages, including 


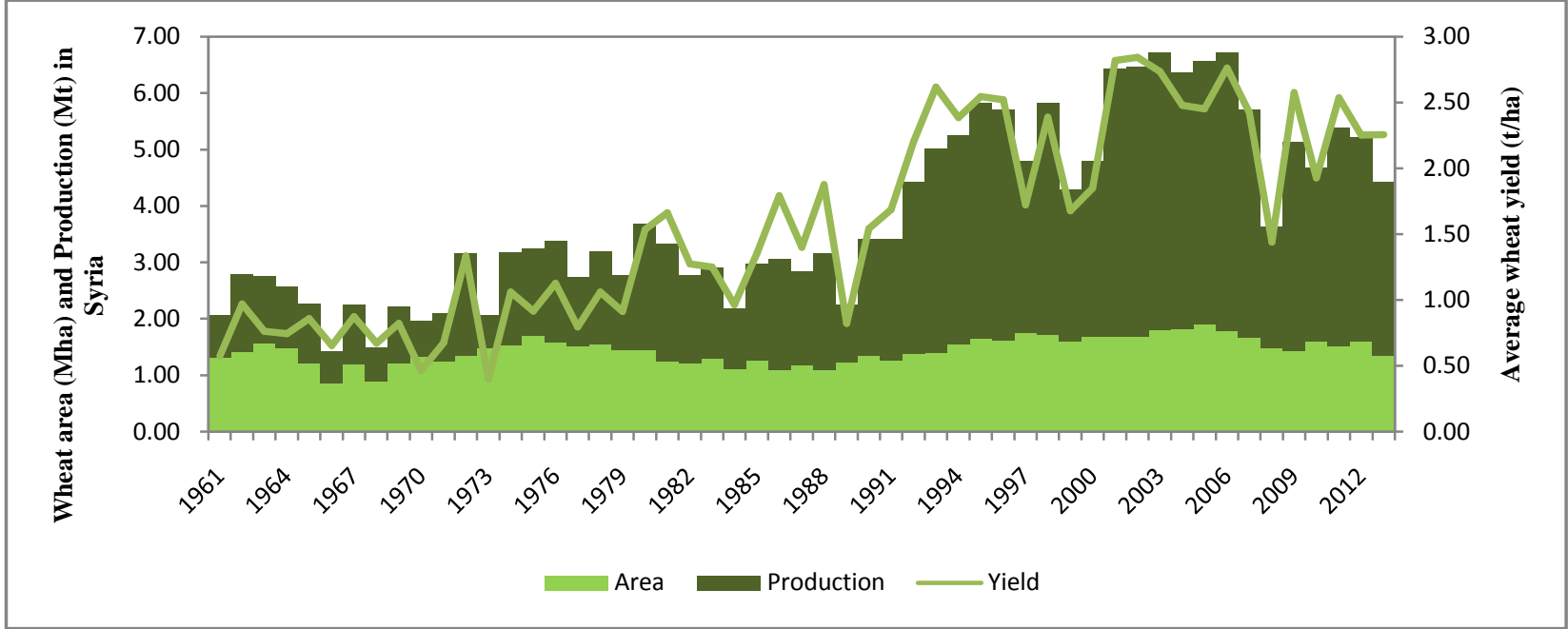

Figure 6 Wheat production, yield, and area from 1961 to 2013 in Syria (FAO, 2014)

improved cultivars, fertilizers, herbicides, fungicides, irrigation, and other technologies.

In Syria, for example, the utilization of agricultural technologies and inputs (improved cultivars, fertilizer, irrigation, etc.) through government led extension system has helped to increase wheat production especially after 1992 (Figure 6). Majd Jamal (2014) has clearly indicated the role of cooperation between the National Research System and several international and regional organizations especially ICARDA in capacity developments and that the joint research led to release the famous Sham series of bread and durum wheat cultivars, which are adapted to both rain- fed and irrigated environments in Syria.

Wheat system intensification by non-governmental organizations has also played a significant role in demonstrating and diffusing wheat technologies, increasing wheat productivity and bolstering food security. Recently, ICARDA in collaboration with the national programs has implemented a project on intensification of wheat technologies in Arab countries.

The project sought to improve wheat production and yields in wheat-based agricultural systems in nine CWANA countries: Algeria, Egypt, Iraq, Jordan, Morocco, Sudan, Syria, Tunisia and Yemen (Figure 7).

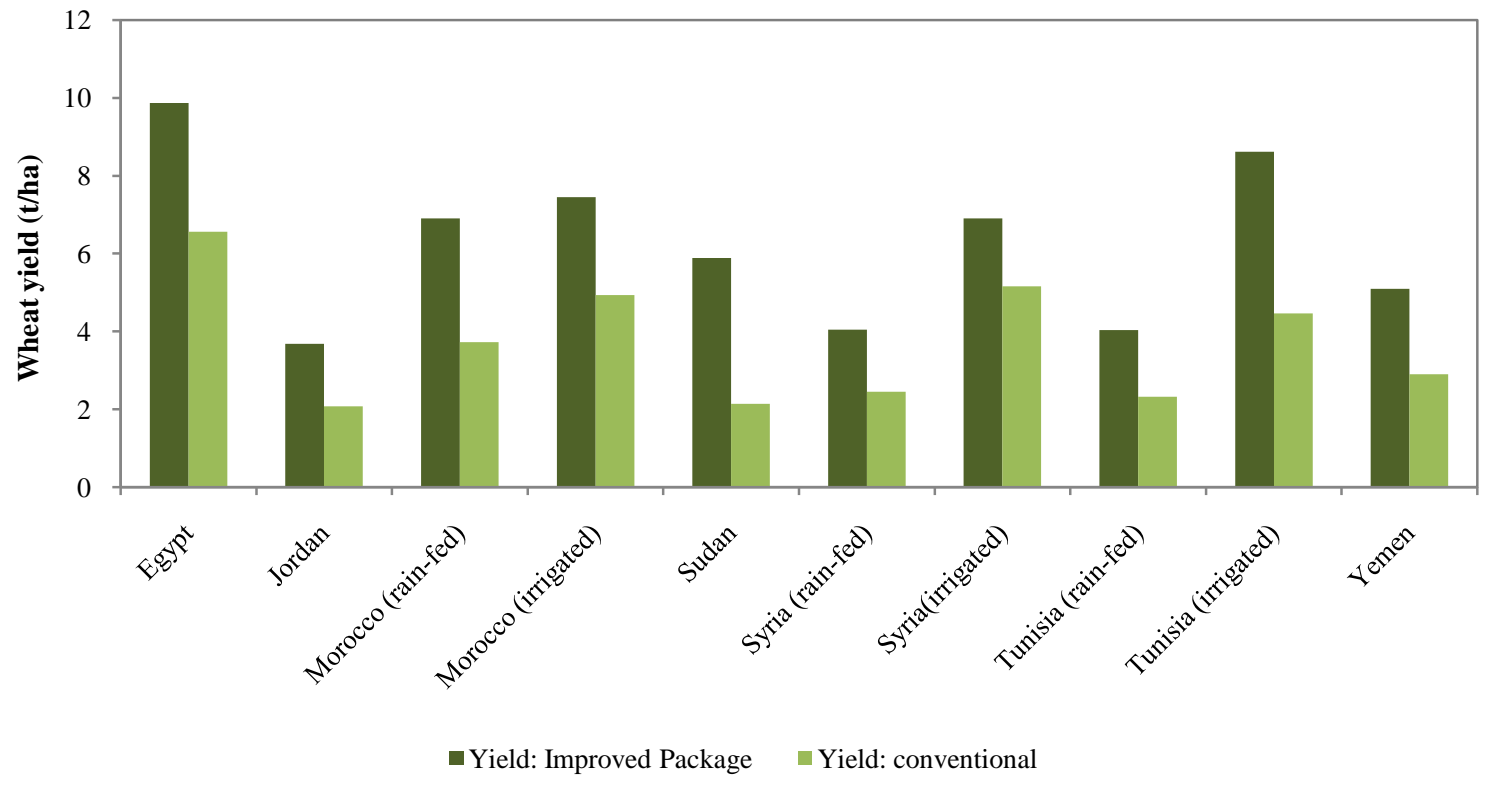

Figure 7 Grain yield of wheat under improved and conventional practices in selected countries, 2011-2013 
Different approaches were followed in each country to disseminate improved wheat management practices (e.g. improved cultivars, fertilizers, irrigation frequency and raised-bed management). Yield results of participating farmers in all countries showed that increases under all production systems (i.e. irrigated, supplementary irrigated or rain-fed) were achievable through the use of improved technologies as compared to the use of farmers' own practices. An average increase of $27 \%$ was achieved in the fields of participating farmers across all countries involved. Taken separately, the maximum average increase per ha was achieved in Sudan (68\% under irrigated wheat systems), and the minimum average increase was recorded in Morocco ( $8 \%$ under rain-fed wheat systems). An impact assessment study conducted in the El Sharkia governorate in Egypt showed that after the implementation of the project, there was an increase in the total amount of certified seeds sold to farmers $(+21 \%)$, in the total area sown in wheat $(+8 \%)$, in the area of wheat grown under raised beds (RB), in the average productivity $(+16 \%)$, and in the total amount of wheat sold to the government $(+36 \%)$. Wheat yield increased from 6.2 t/ha to 7.2 $\mathrm{t} / \mathrm{ha}(+16 \%)$. The improvement in yield led to the increase in AlSharkia's total wheat amount sold to the Ministry of Supply from $557,030 \mathrm{t}$ in 2009 to $755,496 \mathrm{t}$ in $2013(+36 \%)$. The increase has been estimated to be worth about $36,000,000$ US dollars at the conservative wheat price of 180 US dollars per ton (Halila, 2014). In Syria, research results including the new released cultivars, fertilizers recommendations, supplemental irrigation methods and total agricultural practices packages were demonstrated with pioneer farmers through extension service, with the help of ICARDA and other organizations. Demonstrations through field days were conducted and the new technologies were presented to farmers. This approach has enabled Syria to achieve selfsufficiency in wheat and even to export the surplus production (Majd Jamal, 2014). Similarly, systems of wheat intensification (SWI) have been implemented in Nepal by Mercy Corps, a nongovernmental organization, under the EU-FAO Food Facility Program. System of wheat Intensification practices using modern wheat cultivars raised wheat yields by $91 \%$, reaching a yield of 6.5 ton/ha, compared to the control (3.4 t/ha) (Khadka \& Raut, 2011) in Nepal. The sustainability and continuity of intensification programs depend on many factors including profitability, access to market, inputs, information, capacity building, subsidies, and conducive policies.

\section{The Way Forward}

\subsection{Exploring adaptive genes from genetic resources}

Genetic resources remain a major source of genes to overcome the major biotic and abiotic stresses and for improving further the quality and nutritional attributes. CIMMYT and ICARDA genebanks hold the largest collection of wheat genetic resources available to all partners around the world. ICARDA genebank holds "in-trust" around 41,300 accessions in its active collection (Table X). This is a unique collection as it has more than $80 \%$ of landraces and one the richest Aegilops collection.

The landraces were extensively used wild relative species are increasingly used to broaden the genetic base and to improve yield under harsh conditions and resistance to major diseases and pests. The Focused identification of Germplasm Strategy (FIGS), basing its sub-setting approach on algorithms linking the after-sought traits with environmental characteristics of the collecting sites, is used to select best bet sub-sets for different traits (Street et al., 2008). This approach showed its relevance and has allowed the identification of first sources of resistance to Sunn pest at seedling stage, many sources of resistance to Russian wheat aphid, new alleles for powdery mildew and accessions with better drought and salinity tolerances (El-Bouhssini et al., 2009; Endresen et al., 2011; Bari et al., 2012). Although wheat was among few crops which benefited from wide crosses, more coordinated prebreeding efforts are needed in the future to tackle the complex traits related to tolerance to heat, drought, salinity and the emerging diseases/pest and new virulences. The accumulated experience of using wild relatives is promising and highly rewarding as shown in the case of development and use of synthetic hexaploid wheat's derived from Aegilop stauschii, which represent $35 \%$ of the elite germplasm developed by ICARDA and CIMMYT.

\subsection{Adopting climate smart wheat technologies}

Wheat is the most water use efficient among the three major cereals (i.e. wheat, rice, maize) as reflected by the fact that the major wheat exporting countries such as Australia, United Sates, Kazakhstan, and Russia produce wheat under rain-fed conditions. It is anticipated that because of climate change, water will be a major limitation for wheat production even in irrigated environments, in addition to increased heat stress. As a result, wheat is expected to be increasingly grown in rain-fed environments. It is therefore important to develop climate smart wheat cultivars combining high yield potential with resistance/tolerance to drought and heat stresses, in order to cope with the increasing effect of climate change and thereby to produce more grains per drop of water. Furthermore, climate smart technologies such as improved water harvesting techniques, drip irrigation, conservation agriculture, fertigation, and sitespecific nutrient management need to be implemented and promoted in order to enhance sustainable wheat production.

\subsection{Improving Integrated pest management practices}

Integrated Pest Management (IPM) is a sustainable approach to managing pests such as weeds, diseases and insects by combining cultural, physical, chemical and biological tools in a way that minimizes economic, health and environmental risks. This diverse approach has the potential to substantially reduce the use of 
chemicals, while providing a high level of effective pest management. However, it requires a higher degree of commitment and awareness creation from policy makers and extension agents about safety, feasibility and productivity of IPM packages in order to implement and promote them at farm level.

\subsection{Establishing strong seed systems}

Efficient and effective seed delivery systems are critical for new crop cultivars - including new wheat cultivars - to reach farmers and bring meaningful impact. Many national seed systems in the developing countries are weak and operate under heterogeneous agro-ecological farming system, crop and market environments. They also face a broad range of constraints such as poor policy and regulatory frameworks; inadequate institutional and organizational arrangements; deficiencies in production, processing, and quality assurance infrastructure; poorly trained personnel, and limiting technical and managerial capacities, compounded by farmers' difficult socio-economic circumstances. It is therefore crucial to assist and strengthen NARS in managing a strong seed system through capacity development, establishing fast-track variety release systems, participatory demonstrations and accelerated seed multiplication of newly released wheat cultivars to ensure fast replacement of existing vulnerable commercial cultivars.

\subsection{Improving grain quality -segregation for added-value}

With increasing incomes of many global consumers, the demand for specific wheat quality attributes and products is increasing. This creates a differentiation of wheat products in markets, based on visible or non-visible characteristics and opens the possibility of adding value to the wheat industry, creating extra employment along value chains, and increasing farm gate prices. The willingness to pay premium price for high quality wheat encourages farmers to grow wheat cultivars with known quality profiles and reasonably good yield potential. In this regard, it is noteworthy that it is possible to improve the nutritional value of wheat by introgressing genes for high quality proteins and micronutrients such as iron and zinc. This effort, however, requires investment in research, institution capacity building for varietal classification, grading into different wheat classes, and raising public awareness.

\subsection{Promoting enabling policies and working environments}

For sustainable wheat production, favorable and conducive government policies play an important role. Government subsidies to agricultural inputs such as improved seed, irrigation water, and chemicals encourage farmers to adopt improved wheat technologies and increase wheat production. Furthermore, creation of adequate infrastructures and marketing systems is of paramount importance for having a successful and competent wheat industry at national and regional levels.

\subsection{Strengthening regional and international Networks}

The International Wheat Improvement Network (IWIN) and currently the WHEAT CRP, an alliance of international Centers (CIMMYT and ICARDA), NARS, universities and regional institutions has been a successful and efficient network for making distributing globally new wheat genotypes (Payne, 2004; Dixon et al., 2009; Byerlee \& Dubin, 2010). Such a network could be strengthened by widening partnerships and collaboration, in order to develop, disseminate, and market more productive, stress tolerant, and nutritive wheat cultivars, and to perfect and promote production practices based on the principles of conservation agriculture, which boost yields while conserving or enhancing critical resources like soil and water.

\section{References}

Bari A, Street K, Mackay M, Endresen DTF, De Pauw E, Amri A (2012) Focused Identification of germplasm strategy (FIGS) detects wheat stem rust resistance linked to environmental variables. Genetic Resources and Crop Evolution59 : 14651481.doi:10.1007/s10722-011-9775-5.

Bishaw Z (2004) Wheat and barley seed systems in Ethiopia and Syria. Wageningen, the Netherlands: Wageningen University.

Braun HJ, Atlin G, Payne T (2010) Multi-location testing as a tool to identify plant response to global climate change. In: Reynolds MP (Ed.) Climate change and crop production. CABI International, Pp 115-138.

Byerlee D, Dubin HJ (2010) Crop Improvement in the CGIAR as a global success story of open access and international sharing. International Journal of the Commons 4:452-480.

Dixon J, Braun HJ, Kosina P, Crouch J.H (Eds.) (2009) Wheat Facts and Futures 2009. Mexico, DF (Mexico): CIMMYT, Pp. 95.

El Bouhssini M, Ogbonnaya FC, Chen M, Lhaloui S, Rihawi F, Dabbous A (2012) Sources of Resistance in Primary Synthetic Hexaploid Wheat (Triticum aestivum L.) to Insect Pests - Hessian fly, Russian wheat aphid and Sunn pest in the Fertile Crescent. Genetic Resources and Crop Evolution 60: 621-627.DOI 10.1007/s10722-012-9861-3.

El-Bouhssini M, Street K, Joubi A, Ibrahim Z, Rihawi F (2009) Sources of Wheat resistance to Sunn pest, Eurygaster integriceps Puton, in Syria. Genetic Resources and Crop Evolution 56 :10651069.

Endresen DTF, Street K, Mackay M, Bari A, De Pauw E (2011) Predictive association between biotic stress traits and ecogeographic data for wheat and barley landraces. Crop Science 51:2036-2055. 
Evans J, McNeill AM, Unkovich MJ, Fettell NA, Heenan DP (2001) Net nitrogen balances for cool-season grain legume crops and contributions to wheat nitrogen uptake: a review. Animal Production Science $41: 347-359$.

FAO (2014) FAOSTAT, FAO, Rome, Italy. Available on http://faostat.fao.orgaccessed on 27 December 2015.

FAO (2015) FAOSTAT, FAO, Rome, Italy. Available on http://faostat.fao.orgaccessed on 14 September 2015.

FAO (2017) FAOSTAT, FAO, Rome, Italy. Available on http://faostat.fao.org accessed on 20 May 2017.

Ferrara O, Mulitze D, Yau SK (1987) Bread wheat breeding for tolerance to thermal stresses occurring in West Asia and North Africa. In: Acevedo E, Fereres E, Gimenez C, Srivastava JP (Eds.) Improvement and management of winter cereals under temperature, drought stresses, Pp 267-282

Fischer RA, Byerlee D, Edmeades GO (2014) Crop yields and global food security: will yield increase continue to feed the world? ACIAR Monograph No. 158. Australian Centre for International Agricultural Research: Canberra. xxii + Pp. 634.

Halila H (2014) Enhancing Food Security in Arab Countries Project. In: Sadik AK, El Solh M, Saab N (Eds.) Food Security in Arab Countries, Annual Report of Arab Forum for Environmental Development.

ICARDA (2013) ICARDA annual report. Beirut, Lebanon

Ilbeyi A, Ustun H, Oweis T, Pala M, Benli B (2006) Wheat water productivity in a cool highland environment: Effect of early sowing with supplemental irrigation. Agricultural Water Management $82: 399-410$.

Khadka RB, Raut P (2011) System of Wheat Intensification (SWI): A new concept on low input technology for increasing wheat yield in marginal land. System of Rice Intensification website. Report on a SWI project in Far Western Nepal by European Union Food Facility Project, Forum for Awareness and Youth Activity Nepal and Safety Nets Supporting Agricultural Productivity (SNAP) Mercy Corps Nepal

Lhaloui S, Buschman L, El Bouhssini M, Amri A, Hatchett JH, Keith D, Starks K, El Houssaini K (1992) Control of Mayetiola species (Diptera: Cecidomyiidae) with carbofuran in bread wheat, durum wheat and barley, with yield loss assessment and its economic analysis. Awamia 77: 55-73.

Majd Jamal (2014) Enhancing Wheat Self Sufficiency in Syria. In: Sadik AK, El Solh M, Saab N (Eds.) Arab Environment: Food Security. Annual Report of the Arab Forum for Environment and Development, Beirut, Lebanon. Technical Publications.
Manes Y, Gomez HF, Puhl L, Reynolds M, Braun HJ, Trethowan R (2012) Genetic yield gains of the CIMMYT international semiarid wheat yield trials from 1994 to 2010 . Crop Science 52 : 1543 1552 .

Moussadek R (2012) Impacts de l'agriculture de conservation sur les propriétés et laproductivité des vertisols du Maroc Central. $\mathrm{PhD}$ thesis submitted to the University of Ghent, Belgium.

Moussadek R, Mrabet R, Dahan R, Douaik A, Verdoodt A, Van Ranst E, Corbeels M (2011) Effect of tillage practices on the soil carbon dioxide flux during fall and spring seasons in a Mediterranean Vertisol. Journal of Soil Science and Environmental Management 2 : 362-369.

Moussadek R, Mrabet R, Dahan R, Zouahri A, El Mourid M, Van Ranst E (2014) Tillage system affects soil organic carbon storage and quality in central Morocco. Applied and Environmental Soil Science, Article ID $654796 . \quad$ DOI: http://dx.doi.org/10.1155/2014/654796.

Mrabet R, Moussadek R, Fadlaoui A, van Ranst E (2012) Conservation agriculture in dry areas of Morocco. Field Crops Research 132: 84-94.

Nagarajan S (2005) Can India produce enough wheat even by 2020. Current Science 89 : 1467-1471.

Pala M, Oweis T, Benli B, De Pauw E, El Mourid M, Karrou M, Jamal M, Zencirci N (2011) Assessment of wheat yield gap in the Mediterranean: case studies from Morocco, Syria and Turkey. International Center for Agricultural Research in the Dry Areas (ICARDA), Aleppo, Syria.iv +Pp36.

Passioura JB, Angus JF (2010) Improving Productivity of Crops in Water-Limited Environments. Advances in Agronomy 106: $37-$ 75.

Payne T (2004)The international wheat improvement network (IWIN) at CIMMYT. Available on www.cimmyt.org access on $25^{\text {th }}$ January, 2016.

Pieri C, Evers G, Landers J, O’Connell P, Terry E (2002) No-Till Farming for Sustainable Rural development, Agriculture and Rural Development Working Paper, Washington DC: World Bank/ International Bank for Reconstruction and Development.

Rajaram S, van Ginkel M, Fischer RA (1995) CIMMYT's wheat breeding mega-environments(ME). In: Proceedings of the 8th International Wheat Genetic Symposium, July 19-24, 1993.Beijing, China.

Regar PL, Rao SS, Vyas SP (2005) Crop-residue management for increased wheat (Triticum aestivum) production under saline soils of arid fringes. Indian Journal of Agriculture Sciences 75 : 83-86. 
Reynolds M, Borlaug NE (2006) Impacts of breeding on international collaborative wheat improvement. Journal of Agricultural Science 144: 3-17.

Sharma RC, Crossa J, Velu G, Huerta-Espino J, Vargas M, Payne TS, Singh RP (2012) Genetic gains for grain yield in CIMMYT spring bread wheat across international environments. Crop Science 52:1522-1533

Shiferaw B, Smale M, Braun HJ, Duveiller E, Reynolds M, Muricho G (2013) Crops that feed the world 10. Past successes and future challenges to the role played by wheat in global food security. Food Security $5:$ 291-317.

Singh M, Singh VP, Reddy KS (2001) Effect of integrated use of fertilizer $\mathrm{N}$ and FYM or green manure on transformation of NK and $\mathrm{S}$ and productivity of rice-wheat system on a Vertisols. Journal of the Indian Society Soil Science 49:430-435.

Smil V (1999) Nitrogen in crop production: An account of global flows. Global Biogeochemical Cycles 13: 647-662.

Solh M, Nazari K, Tadesse W, Wellings CR (2012) The growing threat of stripe rust worldwide. Borlaug Global Rust Initiative (BGRI) conference, Beijing

Street K, Mackay M, Zuev E, Kaur N, El Bouhssini M, Konopka J, Mitrofanova O (2008) Diving into the genepool: a rational system to access specific traits from large germplasm collections. In Appels R, Eastwood R, Lagudah R, Langridge E, Mackay M (Eds.) Proceedings of the 11th International Wheat Genetics Symposium, Brisbane, Australia Pp: 28-31.

Tadesse W, Abdalla O, Ogbonnaya F, Nazari K, Tahir I, Baum M (2012a) Agronomic Performance of Elite Stem Rust Resistant Spring Wheat Genotypes and Association among Trial Sites in the
Central and West Asia and North Africa Region. Crop Science 52: 1105-1114.doi: 10.2135/cropsci2011.09.0463

Tadesse W, Inagaki M, Tawkaz S, Baum M, Van Ginkel M (2012b) Recent advances and application of doubled haploids in wheat breeding. African Journal of Biotechnology 11: 1548415492. DOI: http://dx.doi.org/10.5897/AJB12.2124.

Tadesse W, Manes Y, Singh R, Payne T, Crossa J, Braun HJ (2010) Adaptation and performance of CIMMYT spring wheat genotypes targeted to high rain fall areas of the world Crop Science 50: 240-248.

Tadesse W, Morgounov AI, Braun HJ, Akin B, Keser M, Yuksel Kaya, Sharma RC, Rajaram S, Singh M, Baum M, van Ginkel M (2013) Breeding progress for yield and adaptation of winter wheat targeted to irrigated environments at the International Winter Wheat Improvement Program (IWWIP). Euphytica 194:177-185

Tadesse W, Nachit M, Abdalla O, Rajaram S (2016) Wheat Breeding at ICARDA: Achievements and Prospects in the CWANA Region. In Bonjean A, Angus B, van Ginkel M (Eds.).The World Wheat BooK Volume 3. A History of Wheat Breeding. Lavoiseier, Paris. ISBN: 9978-2-7430-2091-0.

Trethowan RM, Reynolds MP, Ortiz-Monasterio JI, Ortiz R (2007) The genetic basis of the green revolution in wheat production. Plant Breeding Reviews 28, 39-58.

van Ginkel M, Trethowan RM, Ammar K, Jiankang Wang, Lillemo M (2002) Guide to bread wheat breeding at CIMMYT. Wheat special report no. 5 (revised edition), Mexico, D.F.: CIMMYT

World Bank (2008) World development report.The World Bank, Washington D.C. 